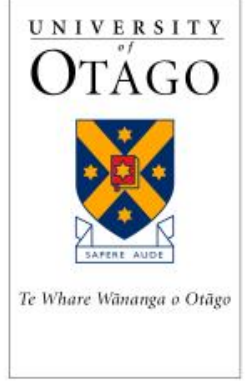

\title{
Information, Institutions and Banking Sector Development in West Africa ${ }^{\S}$
}

Panicos Demetriades ${ }^{\Uparrow}$ and David Fielding ${ }^{\dagger}$

\footnotetext{
${ }^{\S}$ We acknowledge financial support from the ESRC (RES-000-22-2774). We have benefited from extensive discussions with Svetlana Andrianova and Badi Baltagi, and from research assistance provided by Chris Haig. Comments on an earlier draft by George Anayiotos are gratefully acknowledged.

${ }^{\complement}$ Department of Economics, University of Leicester.

$\dagger$ Department of Economics, University of Otago.
} 


\section{Abstract}

Using a new panel dataset for banks in eight West African countries, we explore the factors that exacerbate or alleviate excess liquidity, and the factors that promote or retard the rate of growth of banks' assets. Loan default rates in the region are high, and variations in the rate impact on liquidity and asset growth. However, the size of this effect is very sensitive to bank age. Some types of improvement in the quality of governance reduce excess liquidity and promote asset growth. However, the impact of other types of improvement, particularly with regard to corruption, is ambiguous. We uncover evidence that provides an explanation for this ambiguity.

JEL classification: G21, O16

Key words: Africa, Banking, Default, Institutions, Liquidity 


\section{Introduction}

Banks and other financial intermediaries can perform an important developmental function, especially in Africa, where alternative sources of finance are limited or non-existent. By providing firms with essential finance, they help them to take advantage of productive investment opportunities which may not otherwise materialise. By screening loan applicants, they can help to address adverse selection in the credit market and channel funds towards productive uses. By monitoring borrowers, they can contain moral hazard behaviour, for example, excessively risky investment activity that could undermine a borrower's ability to repay a loan. Through long-term bank-borrower relationships, well established banks can address both adverse selection and moral hazard. This not only helps banks to remain solvent but also ensures that bank finance is channelled towards productive and sound investments.

There is a large body of empirical evidence which suggests that the development of banking systems goes hand in hand with economic development (see for example Levine, 2004). Although the evidence on causality is mixed, there is broad consensus that well functioning banking systems can and do promote economic growth (Demetriades and Andrianova, 2005). It is, therefore, a puzzle that so many countries remain financially under-developed. This is particularly true of Sub-Saharan Africa, which remains one of the most financially under-developed regions in the world. A recent study by the World Bank has shown that African banking systems lack depth compared to other regions in the world but are also excessively liquid (Honohan and Beck, 2007). According to the World Bank, banks themselves complain that there is a lack of creditworthy borrowers while at the same time households and firms find finance as a major constraint in their activities. The evidence presented by the World Bank also suggests that the least developed banking systems are also the most liquid ones, hence the implication is that excess liquidity is a feature of financial underdevelopment.

This paper aims to shed light on both these features of financial under-development in Africa, utilising a panel data set that includes all banks operating in the West African Economic and Monetary Union (UEMOA) during 2000-20005. The UEMOA provides a uniform financial system across eight countries; the structure of this system has changed little in the last 15 years. Therefore, we can be sure that the variations in bank behaviour we observe within the UEMOA are not due to variations in the nature of public financial institutions which the banks face. This makes feasible the identification of the institutional sources of the variations in bank behaviour, which are not correlated with variations in the quality of public financial institutions. Our dataset includes balance sheet information on each bank in the UEMOA, including information on loan defaults as well as bank 
characteristics such as age and ownership type. We use the default data to calculate average loan default rates in each country, which we use as a proxy for the quality of borrowers that banks face in the country. We combine this information with macroeconomic data including institutional quality indices constructed by the World Bank. Our dataset enables us to examine the extent to which informational and institutional factors, and interactions between different factors, can explain a bank's loans to assets ratio, which is an inverse measure of bank liquidity. Our dataset can also be used to examine the microeconomic and macroeconomic determinants of bank asset growth.

Our results suggest that both features of financial under-development highlighted by the World Bank report can to a large extent be attributed to severe informational problems. These problems are particularly acute for younger banks, while the more established banks are less affected. Thus our results highlight the critical importance of information capital in both developing banking systems and reducing excess liquidity. Our results suggest that it is not so much the lack of credit worthy borrowers that is the obstacle but the lack of a developed infrastructure that would enable new banks to screen and monitor borrowers. This result is consistent with evidence on the importance of credit registries in reducing credit constraints (Galindo and Miller, 2001). Our results also suggest that bank development in Africa does indeed follow economic development but it is also sensitive to political stability. Finally, and perhaps most interestingly, our findings suggest that the control of corruption affects different types of banks differently. Only the younger domestically owned private banks are found to benefit from this.

The paper is structured as follows. Section 2 reviews the institutional setting within which commercial banks in the UEMOA operate, and provides the conceptual background for our analysis. Section 3 describes the data and modelling strategy. Section 4 presents and discusses the empirical findings. Section 5 summarises and concludes.

\section{Commercial Banking in the UEMOA}

The UEMOA is a monetary union arising from the final phase of French colonialism in West Africa (1948-1962), and encompasses most of France's former colonies in the area. The current member states are Benin, Burkina Faso, Cote d'Ivoire, Guinea-Bissau, ${ }^{1}$ Mali, Niger, Senegal and Togo. It forms part of the Franc Zone, the other main component of which is a second monetary union, the Economic and Monetary Community of Central Africa (CEMAC). The cornerstone of the Franc Zone is the use of currencies that the French Treasury guarantees to exchange for Euros at a fixed rate. (Rather confusingly, the UEMOA currency and the CEMAC currency are both called the CFA

\footnotetext{
${ }^{1}$ Guinea-Bissau is a small, relatively underdeveloped former Portuguese colony. It joined the UEMOA in 1985.
} 
Franc, although they are two entirely different currencies. ${ }^{2}$ The arrangements that the two monetary unions have with the French Treasury are parallel but entirely independent of each other.)

The enduring institutional link with the former colonial power gives the UEMOA countries an unusually high level of financial stability, compared to other African countries with similar levels of economic development. The institutional framework is defined by a constitutional accord dating from the period in which the colonies became fully independent (1960-1962), and preserving many of the features of the financial system of post-war French colonial Africa. The main features are as follows.

(i) Guaranteed convertibility. Article 1 of the accord stipulates that France will help UEMOA member states to ensure the free convertibility of their currency. In practice, this means that the French Treasury will exchange CFA Francs for Euros on demand. Lending by the BCEAO (the UEMOA central bank) to domestic governments and to the private sector is now limited by rules designed to prevent free-riding on the French guarantee.

(ii) A fixed exchange rate. Up until 1994, Article 2 of the accord stipulated a fixed rate of 50 CFA Francs to one French Franc. The rate has been changed only once, to 100:1, in January 1994. The entry of France into the European Monetary Union means that the rate is now defined in terms of Euros, but the current Euro rate (655.957:1) is equivalent to 100:1 against the French Franc.

(iii) Free transferability. Article 6 of the accord describes the 'freedom of financial relations between France and members of the Union'. This obligation on the part of the African states is not without qualification, and the practice of member states has not always been in harmony with the principle. International capital transfers are taxed, and occasionally (especially during the run-up to the devaluation in 1993) the transferability has been suspended. Nevertheless, there is usually a reasonable degree of capital mobility between the UEMOA and France.

(iv) Harmonization of rules governing currency exchange. Article 6 of the accord notes that the 'uniform regulation of the external financial relations of member states ... will be maintained in harmony with that of the French Republic'. These regulations cover such things as the remittance of salaries abroad (that is, outside the Franc Zone), foreign investment and borrowing from abroad.

(v) A common regulatory framework. Regulation of the banking system is the responsibility of the UEMOA Banking Commission, which was created in 1990 with French technical support. The

\footnotetext{
${ }^{2}$ CFA originally stood for Colonies Françaises en Afrique. It now stands for Communauté Financière Africaine (for the UEMOA currency) and Cooperation Financière en Afrique (for the CEMAC currency).
} 
commission has oversight over the day-to-day activities of all banks and other financial institutions in the UEMOA, and has the power to intervene in the operations of individual banks when its rules are infringed. In the case of serious infractions, the commission can impose disciplinary sanctions of differing degrees of severity, ranging from a formal warning to the dismissal of senior bank officials and suspension of a bank's activities. Commission staff produce regular reports on the extent of compliance with UEMOA banking regulations; the loan default data used in this paper are taken from statistics compiled by the Banking Commission.

The financial stability provided by these institutions means that commercial banks in the UEMOA are free from some of the uncertainties facing financial institutions in other parts of Africa; the same is true of depositors. However, other risks remain. Firstly, many banks are likely to face a serious adverse selection problem arising from variations in borrowers' creditworthiness. In theory, this should depress the equilibrium volume of loans (Stiglitz and Weiss, 1981, 1983). Existing evidence indicates that the magnitude of the problem can vary across countries and over time, and is likely to depend not only on institutional quality but also on business cycle variables (Fuentes and Maquiera, 2001; Koopman et al., 2005). One measure of the average level of creditworthiness in a country is the average rate of default on loans. (A higher default rate entails lower creditworthiness.) As we will see later, the rate of default on bank loans exceeds $10 \%$ in our sample. However, there is a great deal of variation in the average default rate across countries and over time: in some countries the rate sometimes dips below 5\%, while in others it occasionally exceeds $30 \%$. Variations in the overall rate of default in a country could have a large impact on the profitability of lending, and therefore on both the loans-assets ratio and the rate of growth of bank assets and liabilities. ${ }^{3}$

Secondly, corruption could make loans less profitable, if it means that banks are forced to ignore the commercial worth and riskiness of projects they finance for the political elite. Direct evidence of such corruption in Kenya is discussed by Bigsten and Moene (1996), and evidence for a link between the corruption of bank officials and the productivity of investments is discussed by Beck et al. (2005). Such corruption will tend to reduce the loans-assets ratio, and may also depress asset and liability growth (unless the banks in question raise deposits from the corrupt elite).

\footnotetext{
${ }^{3}$ There is also some variation in default rates across banks. One alternative modelling strategy is to condition bank behaviour on bank-specific rather than national default rates. However, we do not have reliable information on what proportion of the observed default on the loans of an individual bank is predictable, and what proportion is due to unobservable random shocks that should not influence bank decisions in the future. The noise-signal ratio for bankspecific default rates is likely to be much higher than the national default rate.
} 
Thirdly, the quality of contract enforcement and overall political stability in the country could affect the extent of moral hazard that banks face when making loans. Institutions promoting the rule of law are likely to enhance banks' ability to enforce loan contracts, and hence increase a bank's willingness to lend and to grow (Messick, 1999). Institutions could act as a deterrent to moral hazard behaviour by borrowers, helping to reduce the degree of moral hazard faced by banks when they make loans. Governments of some UEMOA countries have enacted legislation to facilitate the recovery of bad debts of individual banks (for example, the BHM in Mali); however, such support for banks is by no means universal.

These factors must be interpreted bearing in mind that many of the banks in our sample are very young. For $25 \%$ of our observations, the age of the bank is seven years or less. For very young banks, raising deposits is likely to be easier than identifying reliable borrowers. Older banks are likely to have more information capital so that their ability to screen borrowers is likely to be better than that of younger banks. The adverse selection problem is likely to be more acute for younger banks, at any given average quality of borrowers. Very young banks are likely to channel most of their resources into building up their deposit base, and deposits might in the first instance be channelled into foreign assets or claims on other domestic financial institutions rather than into business lending. Therefore, very young banks will have a higher total asset and liability growth rate and a lower loans-assets ratio, ceteris paribus. These young banks may also be less sensitive to historical default rates in the country, if the few new borrowers they identify are atypical of existing borrowers. A reduction in the default rate will raise their loans-assets ratio by a smaller amount, and, have less of an impact on their asset growth.

Bank age may also affect the impact of political stability and rule of law on both deposit growth and the loans-assets ratio. Stability may make it easier to form relationships with new depositors, who make up a larger fraction of the customers of new banks, as well as to identify reliable new borrowers. In this case, the impact of stability on deposits on asset and liability growth will decline with bank age. If very young banks face high costs in identifying reliable borrowers, then the growth in deposits following a rise in stability may outstrip their capacity to make new loans, in which case their loans-assets ratio may fall, even if that of older banks is rising.

The effect of controls on corruption may also vary with bank age. Some older banks with ties to the political elite may benefit from corruption, insofar as the elite deposit some of their earnings with these older, established banks. In this case, controlling corruption will reduce older banks' deposit growth, and may benefit younger banks with weaker ties to the political establishment. (However, in testing such a hypothesis, we will also need to control for other bank characteristics, such as the 
extent to which they are state- or foreign-owned.) On the other hand, controlling corruption should encourage all banks to lend a larger fraction of their assets. Even banks benefitting from the deposits of the corrupt elite will be encouraged to lend a larger fraction of their assets, if the loans don't have to be to the elite.

All of these factors are relevant to most African countries. However, in most African countries they are correlated with financial stability, and therefore difficult to identify precisely. We restrict our attention to banks in the member states of the UEMOA in the period 2000-2005. In our sample, the quality of the financial system is uniform over time: there has been no major revision of UEMOA legislation in this period. It is also uniform across countries: there is a single authority - the Banking Commission - responsible for regulating all banks in the monetary union. We can therefore be confident that the effects we identify are not due to variations in the quality of the financial system, but to underlying political institutions. The next section describes the formal model capturing the effects described in this section - a model of the loans-assets ratio and of real asset growth - and the data to which the model will be fitted.

\section{Data and Methodology}

\subsection{Data}

The loans and assets data used in our econometric model are taken from the annual BCEAO publication Bilans des Banques et Etablissements Financiers. ${ }^{4}$ These data are used to construct two dependent variables for bank $i$ in year $t$ : the loans-assets ratio $\left(R A T I O_{i t}\right)$ and real asset growth $\left(G_{R O W T H}\right)$. Annual data are available for 113 banks in the UEMOA over the period 2000-2005: 15 in Benin, 14 in Burkina Faso, 27 in Cote d'Ivoire, two in Guinea-Bissau, 16 in Mali, 11 in Niger, 17 in Senegal and 11 in Togo. RATIO it is constructed as the ratio of commercial loans ("créances sur la clientele") to total assets ("total de l'actif"). GROWTH ${ }_{i t}$ is constructed as the annual change in the log of total assets less the annual change in the log of the consumer price index reported in the BCEAO Annuaire Statistique. Some banks came into existence in the middle of the sample period, so we have an unbalanced panel.

The econometric model also incorporates a number of explanatory variables, as follows. The countrywide default rate facing bank $i$ in year $t\left(D E F A U L T_{i t}\right)$ is the ratio of the total bad debt of all commercial banks in the country in which bank $i$ operates to the total commercial lending of those banks. The figures for bad debt ("crédits en souffrance") are taken from the UEMOA Banking Commission's Rapport Annuel. This publication is also the source of data on the fraction of bank

\footnotetext{
${ }^{4}$ All publications mentioned in this section are available online at www.bceao.int.
} 
capital owned by the government (GOVERNMENT $\left.T_{i t}\right)$ and foreigners $\left(F O R E I G N_{i t}\right)$. Data on the number of years each bank has been in operation by year $t\left(A G E_{i t}\right)$ are taken from the BCEAO publication Annuaire des Banques et Etablissements Financiers de l'UEMOA. Data on real GDP growth in the country in which a bank is operating $\left(G D P G R_{i t}\right)$ are taken from the Annuaire Statistique.

Figures 1-6 illustrate the sample distributions of some of the bank characteristics. It can be seen from Figure 1 (RATIO) that a majority of banks lend between $40 \%$ and $70 \%$ of their assets. However, there is also a substantial fraction lending over $80 \%$, and some lending less than $20 \%$. Figure 2 (GROWTH) shows a similarly wide dispersion in asset growth rates. The percentage annual growth rate for the average bank is in single figures. However, a substantial fraction experience annual growth in excess of $20 \%$, while others see assets fall by over $20 \%$. It remains to be seen which bank characteristics - if any - explain the wide dispersion of both RATIO and GROWTH. Figures 3-6, which illustrate the distributions of $A G E$ and of the bank ownership variables, indicate considerable heterogeneity in these characteristics. A substantial majority of banks are very young, having been established only in the 1980s or later; however, others predate the independence period. Banks that are entirely owned by foreigners, or by the government, or by the domestic private sector, are very common; however, most banks have mixed ownership.

In order to capture the effects of variation in country-specific corruption and ease of contract enforcement, we make use of the indicators reported in the World Bank World Governance Indicators. These indicators are described and discussed in Kaufmann et al. (2007). Our measure of the extent to which a country is corruption-free is the "control of corruption" index in World Governance Indicators. For bank $i$ in year $t, C O N T R O L_{i t}$ indicates the value of the index for the country in which the bank operates. There are several different governance indicators that may be associated with ease of contract enforcement: "rule of law" $\left(L A W_{i t}\right)$, "voice and accountability" $\left(V O I C E_{i t}\right), “ p o l i t i c a l$ stability" $\left(S T A B I L I T Y_{i t}\right)$,"government effectiveness" $\left(\right.$ EFFECT $\left._{i t}\right)$ and "regulatory quality" $\left(Q U A L I T Y_{i t}\right)$. These indictors are quite highly correlated with each other, so it does not make sense to include them all in a single regression equation. However, there are no strong a priori grounds for supposing that one particular indicator is an especially good measure of the extent to which banks are protected from moral hazard effects. The methodology section that follows explains how we deal with the multicollinearity of the governance indicators.

Descriptive statistics for the variables in our model are presented in Table 1. Note that the governance variables are normalised so that the mean of each is equal to zero across a worldwide sample. Negative means in our sample indicate that the UEMOA countries perform below the 
worldwide average in terms of governance, despite their financial stability. On average, the ratio of loans to total assets is $57 \%$ (low by international standards) and the ratio of defaults to total loans is $14 \%$ (high by international standards). However, the standard deviations around these two means are quite high.

\subsection{Methodology}

The discussion in section 2 indicates that the loans-assets ratio (RATIO) may depend on the loan default rate in the country (DEFAULT), control of corruption (CONTROL), the quality of contract enforcement (as captured by one of the other governance indicators), and bank age (AGE). Bank age may also affect the impact of changes in the default rate, control of corruption or contract enforcement on the loans-assets ratio. Since we are using panel data, we should also allow for fixed effects, and for some persistence in the loans-assets ratio, which can be captured by including a lagged dependent variable.

The different governance indicators are quite highly correlated with each other, so fitting a model with more than two indicators does not produce significant coefficients. A sensible model of RATIO will therefore include CONTROL plus one other indicator to capture the ease of contract enforcement. We have no strong a priori view on which of these indicators best captures the contract enforcement effect, so we fit several different models, each with a different indicator ( $L A W$, STABILITY, VOICE, EFFECT, QUALITY). The best-fitting model, reported in Table 2, is the one incorporating $L A W$. This model is of the form:

$$
\begin{aligned}
\text { RATIO }_{i t} & =\alpha_{t}+\beta_{i}+\rho \cdot \text { RATIO }_{i t-1}+\theta \cdot A G E_{i t}+\left[\eta_{0}+\eta_{1} \cdot A G E_{i t}\right] \text { DEFAULT }_{i t} \\
& +\left[\phi_{0}+\phi_{1} \cdot A G E_{i t}\right] \text { CONTROL }_{i t}+\left[\zeta_{0}+\zeta_{1} \cdot A G E_{i t}\right] L A W_{i t}+u_{i t}
\end{aligned}
$$

The $\alpha$ and $\beta$ parameters capture time and bank fixed effects, and $u$ is a regression residual. ${ }^{5}$ Alternative models, in which LAW is replaced by STABILITY, VOICE, EFFECT or QUALITY, are reported in Appendix Table A1. Since LAW and CONTROL are correlated with each other, we also explore the effect on our model of imposing the restriction $\phi_{0}=\phi_{1}=0$, and of imposing the restriction $\zeta_{0}+\zeta_{1}=0$. Table 2 reports these results also.

\footnotetext{
${ }^{5}$ There will be some heterogeneity in the performance of banks that is difficult to measure or observe. Some banks lend almost exclusively to firms in a specific sector; for example, a number of agricultural banks in the Sahelian countries are highly exposed to the cotton-producing sector.
} 
Our second model is designed to explain variations in banks' real asset growth (GROWTH). Our modelling strategy is similar to the one above. However, the GROWTH model contains two additional effects. Firstly, in modelling asset growth we should control for the size of the economy in which a bank is operating. Secondly, as noted in section 2, we need to test whether the effect of governance on asset growth depends on the structure of bank ownership. If a larger share of the bank is owned by the government or by foreigners, this may change the effect that controlling corruption has on asset growth. Again, the multicollinearity between LAW, STABILITY, VOICE, EFFECT and QUALITY precludes the inclusion of more than one of these variables in the regression equation, so we fit a series of regressions, each with a single on of these governance indicators. Now the regression with the best fit is the one incorporating STABILITY. The results from fitting the model with STABILITY are reported in Tables 3-4; the results using alternative governance indicators are reported in Appendix Table A2. The Table 3-4 results are based on a model of the form:

$$
\begin{aligned}
\text { GROWTH }_{i t} & =\alpha_{t}+\beta_{i}+\rho \cdot \text { GROWTH }_{i t-1}+\theta \cdot \text { AGE }_{i t}+\left[\eta_{0}+\eta_{1} \cdot \text { AGE }_{i t}\right] \text { DEFAULT }_{i t} \\
& +\left[\phi_{0}+\phi_{1} \cdot \text { AGE }_{i t}+\phi_{2} \cdot G_{\text {OVERNMENT }}+\phi_{3} \cdot \text { FOREIGN }_{i t}\right] \text { CONTROL }_{i t} \\
& +\left[\zeta_{0}+\zeta_{1} \cdot \text { AGE }_{i t}+\zeta_{2} \cdot \text { GOVERNMENT }_{i t}+\zeta_{3} \cdot \text { FOREIGN }_{i t}\right] \text { STABILITY }_{i t} \\
& +\delta \cdot \text { GDPGR }_{i t}+u_{i t}
\end{aligned}
$$

The coefficient $\delta$ captures the effect on asset growth of overall economic growth, as captured by the rate of growth of real GDP; the parameters $\phi_{2}$ and $\phi_{3}$ capture the effect of bank ownership on the impact of corruption on asset growth, while $\zeta_{2}$ and $\zeta_{3}$ capture the effect of bank ownership on the impact of political stability on asset growth. ${ }^{6}$ Equation (2) contains many interaction terms, and does not provide a direct estimate of the average effect of CONTROL and STABILITY on asset growth. For this reason, we also fit a model with the restriction $\phi_{1}=\phi_{2}=\phi_{3}=\zeta_{1}=\zeta_{2}=\zeta_{3}=0$. The restricted version of the model is reported in Table 3, and the unrestricted version in Table 4. Given the correlation between CONTROL and STABILITY, Table 3 also reports the results of imposing the additional restrictions $\phi_{0}=0$ and $\zeta_{0}=0$.

Since equations (1-2) represent dynamic panel models, we must allow for the endogeneity of the lagged dependent variable. We should also allow for the fact that DEFAULT may be endogenous to RATIO or GROWTH. Tables 2-4 report parameters estimated using the two-step GMM estimator of

\footnotetext{
${ }^{6}$ The ownership variables appear only in interaction terms. If these variables are included in the model as additively separable terms, the coefficients on them are insignificantly different form zero.
} 
Arellano and Bond (1991). Lags up to order three are used as instruments for the lagged dependent variable and up to order two as instruments for DEFAULT and AGE - DEFAULT.

\section{Empirical Results}

Tables 2-4 contain the empirical results. Tables 2 present the results on the loans-assets ratio. Tables 3-4 present the results of models explaining bank asset growth. Supplementary results are provided in Appendix Tables A1-A2.

Table 2 presents regression results corresponding to equation (2). It can be seen from the table that other regression coefficients are almost completely invariant to the restrictions $\phi_{0}=\phi_{1}=0$ and $\zeta_{0}+$ $\zeta_{1}=0$. The estimated effect of CONTROL on RATIO does not depend on whether $L A W$ is included in the model, and the estimated effect of LAW on RATIO does not depend on whether CONTROL is included in the model.

The table provides strong evidence that high default rates represent a major obstacle to bank lending in the UEMOA. The coefficient of the default rate (DEFAULT) is negative and highly significant in all three models and is economically very large. This effect diminishes with the age of the bank, as indicated by the positive sign of the interaction of the default rate with bank age (AGE $\cdot$ DEFAULT). However, the relative size of the coefficients suggest that bank age needs to be around 40 before the bank has enough information capital to overcome the adverse selection effect. For the youngest banks, a percentage point increase in defaults as a fraction of total loans leads to a reduction in the fraction of assets that are loaned of around 0.6 percentage points.

The table shows a negative coefficient on the rule of law variable ( $L A W)$ and a positive coefficient on the interaction term $A G E \cdot L A W$. The loans-assets ratio of young banks falls when the rule of law improves, while the loans-assets ratio of older banks rises. These effects are statistically significant. For banks older than 15 years old, improving rule of law has a positive effect on the loans-assets ratio. These results are consistent with the conjecture that very young banks face high costs in identifying reliable borrowers, so their growth in deposits following a rise in stability outstrips their capacity to make new loans. The coefficient on control of corruption (CONTROL) is statistically insignificant, but the interaction $A G E$ - CONTROL is positive and statistically significant. This suggests that control of corruption has a greater impact on older banks' willingness to lend than on that of younger banks. Overall, improvements in both the rule of law and control of corruption have a positive effect on the loans-assets ratio of older banks, but the effects on younger banks are negative or insignificant. 
The coefficient on the linearly separable AGE term is statistically significant. The coefficient is around 0.01 , implying that an extra year in operation increases the loans-assets ratio by about one percentage point for a bank in a country with governance variables equal to zero (the worldwide mean). For banks in countries with governance variables below the worldwide mean, as they typically are in our sample, the effect is somewhat smaller. The coefficient on the lagged dependent variable is around 0.2-0.3, and significantly greater than zero, implying that there is some persistence in the loans-assets ratio. If there is a shock to the ratio in the current year, $20-30 \%$ of the effect will persist into the following year, and about $5-10 \%$ into the year after that.

Tables 3-4 contain the results of different specifications of our asset growth model. The tables include results using political stability (STABILITY) alongside control of corruption (CONTROL) as governance indicators. Of the other governance variables, only rule of law was found to be significant in any specification. Results using alternative governance indicators are reported in Appendix Table A2. In Table 3 interaction terms with governance variables are excluded, while in Table 4 we allow for the possibility that the age and ownership structure of a bank modifies the impact of control of corruption and political stability on its asset growth.

The negative coefficient on DEFAULT in Table 3 indicates that loan defaults represent a serious obstacle to the growth of bank balance sheets. The positive and significant coefficient on the interaction term AGE - DEFAULT indicates that this effect is declining with the age of the bank. However, for banks younger than 30 years (almost all of the banks in our sample), the overall effect of an increase in DEFAULT on GROWTH is negative, indicating that all but the very oldest banks have insufficient information capital to counteract the negative effect of high default rate. For the youngest banks, a percentage point increase in defaults as a fraction of total loans leads to a reduction in asset growth of over 1.5 percentage points. For the oldest banks, the effect of DEFAULT on GROWTH is insignificantly different from zero.

Age has a negative effect on asset growth: younger banks grow faster than older banks, indicating some convergence in bank size over time. (However, the positive coefficient on AGE $\cdot$ DEFAULT indicates that this convergence effect is attenuated by high default rates.) Growth in real GDP has a positive effect on asset growth, reflecting the macroeconomic relationship between finance and economic development. The coefficient on GDPGR is insignificantly different from unity, implying that a percentage point increase in GDP growth leads to a percentage point increase in asset growth.

As one might expect, there is a positive and significant coefficient on STABILITY in Table 3: on average, banks grow more when there is political stability. This effect does not depend on whether 
CONTROL is included in the regression. Such a categorical result does not apply to the effect of CONTROL. When STABILITY is excluded from the model, the effect of CONTROL on GROWTH is insignificantly different form zero. However, when STABILITY is included alongside CONTROL, the coefficient on the latter is both negative and statistically significant. On average, greater political stability tend to be associated with more control of corruption; however, for a given level of political stability, more control of corruption leads to lower asset growth, on average. In order to see why this is the case we need to move to Table 4, which includes interaction terms in the governance variables.

The model in Table 4 allows the effects of control of corruption and political stability to vary across different types of bank. The interaction terms allow the effects of governance to vary not only with bank age, but also with the type of bank ownership. In the case of STABILITY, the interaction terms produce variables that are so highly collinear that none is statistically significant (Model 1). For this reason, we report the results from a second regression equation in which the STABILITY interaction terms are excluded. In this regression (Model 2), the coefficient on STABILITY is similar in sign and statistical significance to the corresponding coefficient in Table 3. Political stability appears to affect the asset growth of all banks the same way, irrespective of age or ownership type. By contrast, all of the interaction terms in CONTROL are statistically significant. Control of corruption affects different types of bank in a different way. It has the greatest positive impact on the youngest domestically owned private banks. Its impact declines with the age of the bank and the degree of foreign or government ownership. Its effects on the growth of wholly foreign or government owned banks are negative, irrespective of the bank's age. One interpretation of these results is that control of corruption reduces the savings of the corrupt political elite, who are customers of the old, stateowned and foreign (French) banks. At the same time, it increases the savings of those outside the elite, who are customers of young, private banks. However, the first effect outweighs the second, so the control of corruption is associated with lower asset growth overall (Table 3).

\section{Concluding Remarks}

Our results suggest that a major factor explaining why banks in Africa choose to remain excessively liquid is a high default rate among borrowers. The same factor appears to be a serious obstacle to the growth of bank balance sheets. Our results also suggest that older banks suffer less from this problem, which is consistent with an information capital explanation of why banks are reluctant to lend. The greater the information capital of a bank, the more willing it would be to lend all other things equal. To the extent that financial development is expected to come from the emergence and growth of new banks, this problem can be addressed through the development of credit bureaus and 
other mechanisms that help improve information on prospective borrowers (IMF, 2001; Sacerdoti, 2005).

Perhaps our most interesting result is that control of corruption has very different effects on different types of banks. It is most effective for promoting the growth of young privately owned domestic banks. At the other end of the spectrum, it actually deters the growth of foreign or government owned banks, irrespective of age. This suggests that control of corruption creates a more level playing field which encourages the emergence and growth of new banks. Since new banks are likely to take away business from the more established banks, control of corruption may act as a deterrent to the growth of older banks. A similar explanation may be offered for the effects of corruption on different types of ownership. Control of corruption may create a more level playing field which benefits private banks that are less likely to be well connected to the establishment that foreign or government owned banks. Hence, privately owned banks grow at the expense of government or foreign owned banks when control of corruption is increased. These results are consistent with the interest groups explanation of financial under-development put forward by Rajan and Zingales (2003). Older banks, especially those owned by foreigners or the state, are closer to the establishment than younger domestically owned private banks. They stand to lose by competition by new banks which erodes their rents. Hence, they have an incentive to block the entry and growth of new banks. A corrupt environment offers more opportunities for them to succeed in doing so.

In our dataset, the positive effect that control of corruption has on the growth of new privately owned banks is mitigated not only by the reduction in the growth of older banks, but also by the informational constraints that affect the younger banks more than the older banks. Hence, at the aggregate level, it is by no means obvious that control of corruption will have beneficial effects on the growth of the banking system, unless it is also accompanied by policies that improve the informational capital of new banks. This is clearly a question on which further theoretical and empirical research would be useful. The finding that younger banks face more severe informational constraints is consistent with Love and Mylenko (2003), who find that public credit registries benefit younger firms more than older firms.

Our findings are much less ambiguous when it comes to political stability, which we have found to have an unequivocally positive effect on banking development. Political stability seems to affect all banks in the same way. Improvements in political stability, as well as in information capital and wider economic growth, will unambiguously enhance banking sector development in Africa. 


\section{References}

Arestis, P. and Demetriades, P., (1997) "Financial development and economic growth: assessing the evidence", Economic Journal, 107, 783-799.

Arellano, M. and Bond, S. (1991) "Some tests of specification for panel data: Monte Carlo evidence and an application to employment equations", Review of Economic Studies, 58, 277-297.

Beck, T., Demirgüç-Kunt, A. and Maksimovic, V. (2005) "Financial and legal constraints to growth: does firm size matter?" Journal of Finance, 40(1), 137-177.

Bigsten, A. and Moene, K.O. (1996) "Growth and rent dissipation: the case of Kenya," Journal of African Economies, 5: 177-198.

Demetriades, P. and Andrianova, S. (2005) "Sources and effectiveness of financial development: what we know and what we need to know," Research Paper RP2005/76, World Institute for Development Economic Research, Helsinki.

Fuentes, R. and Maquieira, C.P. (2001) "Why borrowers repay: understanding high performance in Chile's financial market," in Pagano, M. (ed.) Defusing Default: Incentives and Institutions, Washington, DC: Inter-American Development Bank/Johns Hopkins University Press.

Galindo, A. and Miller, M. (2001) "Can credit registries reduce credit constraints? Empirical evidence on the role of credit registries in firm investment decisions," presentation to Towards Competitiveness: the Institutional Path, Annual Meeting of the Board of Governors, Inter-American Development Bank and Inter-American Investment Corporation, Santiago, Chile, March 16 (http://socsci2.ucsd.edu/ aronatas/project/academic/Credit\%20Registries.pdf).

Honohan, P. and Beck, T. (2007), Making Finance Work for Africa, Washington, DC: The World Bank.

IMF (2001) Senegal: Financial System Stability Assessment, Country Report 01/189, Washington, DC.

Kaufmann D, Kraay A, Mastruzzi M. (2007) "Governance Matters VI: aggregate and individual governance indicators 1996-2006”, World Bank Policy Research Working Paper 4280.

Koopman, S.J. Lucas, A. and Klaassen, P. (2005) "Empirical credit cycles and capital buffer formation,” Journal of Banking and Finance, 29(12), 3159-3179.

Levine, R. (2004) "Finance and growth: theory and evidence," NBER Working Paper 10766, Cambridge, MA. 
Love, I. and Mylenko, N. (2003) "Credit reporting and financing constraints," World Bank Policy Research Working Paper 3142, Washington, DC.

Messick, R. (1999) “Judicial reform and economic development: a survey of the issues,” World Bank Research Observer, 14(1), 117-136.

Rajan, R. G. and Zingales, L. (2003) "The great reversals: the politics of financial development in the twentieth century", Journal of Financial Economics, 69, 5-50.

Sacerdoti. E. (2005) “Access to bank credit in Sub-Saharan Africa: key issues and reform strategies," IMF Working Paper WP/05/166, Washington, DC.

Stiglitz, J. and Weiss, A. (1981) "Credit rationing in markets with imperfect information," American Economic Review, 71(3), 393-410.

Stiglitz, J. and Weiss, A. (1983) "Incentive effects of terminations: applications to credit and labor markets," American Economic Review, 73(5), 912-927. 
Table 1: Summary Statistics

$\begin{array}{lccccc} & \text { observations } & \text { mean } & \text { s.d. } & \text { minimum } & \text { maximum } \\ \text { RATIO } & 482 & 0.57 & 0.20 & 0.00 & 0.96 \\ \text { GROWTH } & 487 & 5.52 & 1.58 & 1.43 & 8.37 \\ \text { DEFAULT } & 588 & 0.14 & 0.08 & 0.05 & 0.42 \\ \text { FOREIGN } & 582 & 0.54 & 0.36 & 0.00 & 1.00 \\ \text { GOVERNMENT } & 582 & 0.16 & 0.25 & 0.00 & 1.00 \\ \text { AGE } & 588 & 17.3 & 16.1 & 0.00 & 106 \\ \text { VOICE } & 588 & -0.45 & 0.65 & -1.54 & 0.41 \\ \text { STABILITY } & 588 & -0.45 & 0.82 & -2.45 & 0.71 \\ \text { EFFECT } & 588 & -0.68 & 0.40 & -1.44 & 0.04 \\ \text { QUALITY } & 588 & -0.44 & 0.24 & -1.00 & -0.06 \\ \text { LAW } & 588 & -0.67 & 0.44 & -1.57 & -0.04 \\ \text { CONTROL } & 588 & -0.56 & 0.37 & -1.24 & 0.12\end{array}$


Table 2: Alternative Models of the Loans-Assets Ratio (RATIO)

The table reports GMM coefficients using lags up to order 3 as instruments for the lagged dependent variable and up to order 2 as instruments for the default variables. Year fixed effects are also used. Standard errors are in italics, and coefficients significant at the 5\% level are in bold.

\begin{tabular}{|c|c|c|c|}
\hline & MODEL 1 & MODEL 2 & MODEL 3 \\
\hline \multicolumn{4}{|l|}{ Adverse selection } \\
\hline \multirow{2}{*}{ DEFAULT } & -0.6115 & -0.6688 & -0.6542 \\
\hline & 0.2153 & 0.2168 & 0.2098 \\
\hline \multirow{2}{*}{$A G E \times D E F A U L T$} & 0.0183 & 0.0157 & 0.0171 \\
\hline & 0.0052 & 0.0052 & 0.0050 \\
\hline \multicolumn{4}{|l|}{ Moral hazard } \\
\hline \multirow{2}{*}{ LAW } & -0.1253 & & -0.1134 \\
\hline & 0.0495 & & 0.0570 \\
\hline \multirow{2}{*}{$A G E \times L A W$} & 0.0078 & & 0.0064 \\
\hline & 0.0017 & & 0.0022 \\
\hline \multirow{2}{*}{ CONTROL } & & -0.0585 & -0.0071 \\
\hline & & 0.0359 & 0.0388 \\
\hline \multirow{2}{*}{$A G E \times C O N T R O L$} & & 0.0078 & 0.0031 \\
\hline & & 0.0013 & 0.0015 \\
\hline \multicolumn{4}{|l|}{ Conditioning variables } \\
\hline \multirow{2}{*}{ RATIO $_{-1}$} & 0.2182 & 0.3273 & 0.2314 \\
\hline & 0.0575 & 0.0596 & 0.0614 \\
\hline \multirow{2}{*}{$A G E$} & 0.0118 & 0.0084 & 0.0129 \\
\hline & 0.0024 & 0.0013 & 0.0025 \\
\hline \multicolumn{4}{|l|}{ Summary and diagnostic statistics } \\
\hline Number of observations & 290 & 290 & 290 \\
\hline Standard error & 0.0091 & 0.0097 & 0.0091 \\
\hline Sargan Test (p value) & 0.1381 & 0.2359 & 0.1321 \\
\hline 1st-order serial correlation ( $p$ value) & 0.0062 & 0.0037 & 0.0080 \\
\hline 2nd-order serial correlation ( $p$ value) & 0.9305 & 0.9747 & 0.9305 \\
\hline
\end{tabular}


Table 3: Alternative Models of Real Asset Growth (GROWTH)

The table reports GMM coefficients using lags up to order 3 as instruments for the lagged dependent variable and up to order 2 as instruments for the default variables. Year fixed effects are also used. Standard errors are in italics, and coefficients significant at the 5\% level are in bold.

\begin{tabular}{|c|c|c|c|}
\hline & MODEL 1 & MODEL 2 & MODEL 3 \\
\hline \multicolumn{4}{|l|}{ Adverse selection } \\
\hline \multirow{2}{*}{ DEFAULT } & -1.9910 & -1.7502 & -1.7707 \\
\hline & 0.5527 & 0.5107 & 0.4936 \\
\hline \multirow{2}{*}{$A G E \times D E F A U L T$} & 0.0588 & 0.0488 & 0.0586 \\
\hline & 0.0166 & 0.0153 & 0.0162 \\
\hline \multicolumn{4}{|l|}{ Moral hazard } \\
\hline \multirow{2}{*}{ STABILITY } & 0.1280 & & 0.1271 \\
\hline & 0.0370 & & 0.0364 \\
\hline \multirow{2}{*}{ CONTROL } & & -0.1806 & -0.1885 \\
\hline & & 0.0932 & 0.0812 \\
\hline \multicolumn{4}{|l|}{ Conditioning variables } \\
\hline \multirow{2}{*}{ GROWTH $_{-1}$} & 0.0522 & 0.0597 & 0.0565 \\
\hline & 0.0755 & 0.0769 & 0.0744 \\
\hline \multirow{2}{*}{$A G E$} & -0.0073 & -0.0070 & -0.0075 \\
\hline & 0.0015 & 0.0015 & 0.0015 \\
\hline \multirow{2}{*}{ GDPGR } & 1.0000 & 1.0753 & 0.8340 \\
\hline & 0.4844 & 0.4348 & 0.4574 \\
\hline \multicolumn{4}{|l|}{ Summary and diagnostic statistics } \\
\hline Number of observations & 213 & 213 & 213 \\
\hline Standard error & 0.0557 & 0.0570 & 0.0557 \\
\hline Sargan Test ( $p$ value) & 0.4189 & 0.2268 & 0.3704 \\
\hline 1st-order serial correlation ( $p$ value) & 0.0055 & 0.0051 & 0.0046 \\
\hline 2nd-order serial correlation (p value) & 0.8525 & 0.4415 & 0.7292 \\
\hline
\end{tabular}


Table 4: Models of Real Asset Growth including Interaction Terms

The table reports GMM coefficients using lags up to order 3 as instruments for the lagged dependent variable and up to order 2 as instruments for the default variables. Year fixed effects are also used. Standard errors are in italics, and coefficients significant at the 5\% level are in bold.

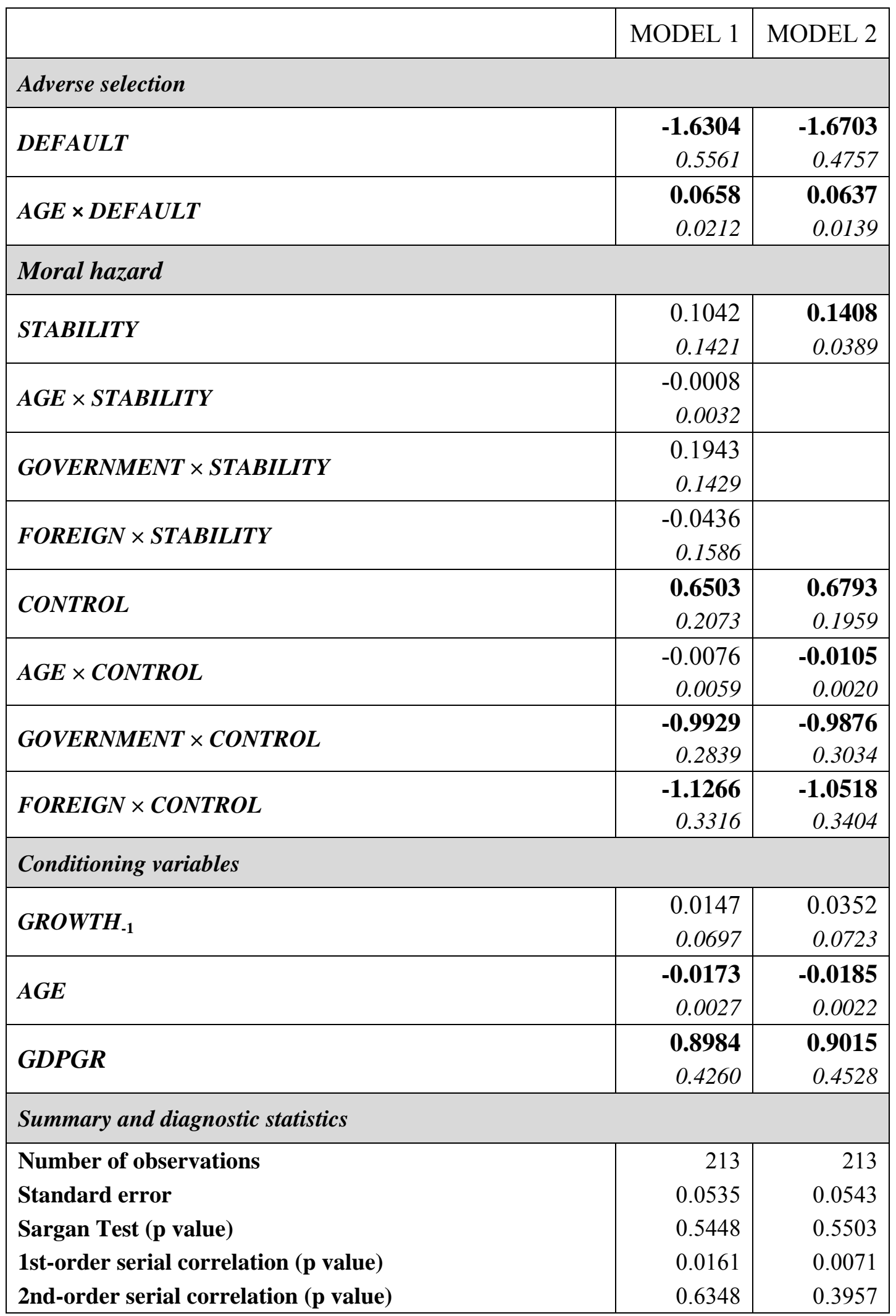




\section{Appendix: Alternative Models of the Loans-Assets Ratio and of Real Asset Growth}

This appendix includes alternative regression equations in which the governance indicators used in Tables 2-3 are replaced by alternative indicators. Table A1 supplements Table 2, and Table A2 supplements Table 3.

Table A1 presents results from models of the loans-assets ratio that replace $L A W$ with one of STABILITY, VOICE, EFFECT and QUALITY. In all four cases, the equation standard errors are higher than in Table 2. In all four cases, the estimated effects of the governance indices are positive at $A G E=0$ but declining in $A G E$. However, the associated standard errors are quite high, and for most values of $A G E$ the marginal effect of a change in the value of the governance index is insignificantly different from zero. None of the coefficients on four alternative governance indices is statistically significant when $L A W$ is added to the regression. The coefficients on all of the other variables in Table A1 are quite similar to the equivalent coefficients in Table 2. The coefficient on the default rate is negative and highly significant as before, although it exhibits some variation according to the governance indicator used in the regression. The coefficients on $A G E$ and $A G E \cdot D E F A U L T$ remain positive and significant, suggesting that the information capital story remains intact.

Table A2 shows that the only governance indicator other than STABILITY having a significant impact on GROWTH is $L A W$; all other indicators are statistically insignificant. Although the $L A W$ coefficient is positive and significant, it loses all significance when $L A W$ it is included in a regression alongside STABILITY. 
Table A1: More Models of the Loans-Assets Ratio (RATIO)

The table reports GMM coefficients using lags up to order 3 as instruments for the lagged dependent variable and up to order 2 as instruments for the default variables. Year fixed effects are also used. Standard errors are in italics, and coefficients significant at the 5\% level are in bold.

\begin{tabular}{|c|c|c|c|c|}
\hline & \multicolumn{4}{|c|}{ type of institution } \\
\hline & VOICE & STABILITY & EFFECT & QUALITY \\
\hline \multicolumn{5}{|l|}{ Adverse selection } \\
\hline \multirow{2}{*}{ DEFAULT } & -0.7440 & -0.6605 & -0.2954 & -0.3660 \\
\hline & 0.2548 & 0.2092 & 0.2630 & 0.2261 \\
\hline \multirow{2}{*}{$A G E \times D E F A U L T$} & 0.0172 & 0.0136 & 0.0009 & 0.0063 \\
\hline & 0.0073 & 0.0067 & 0.0081 & 0.0064 \\
\hline \multicolumn{5}{|l|}{ Moral hazard } \\
\hline \multirow{2}{*}{ institution } & 0.1486 & 0.0538 & 0.1277 & 0.1022 \\
\hline & 0.1132 & 0.0267 & 0.0692 & 0.0708 \\
\hline \multirow{2}{*}{$A G E \times$ institution } & -0.0014 & -0.0013 & -0.0050 & -0.0089 \\
\hline & 0.0036 & 0.0012 & 0.0020 & 0.0030 \\
\hline \multirow{2}{*}{ CONTROL } & -0.0661 & -0.0609 & -0.1604 & -0.1330 \\
\hline & 0.0290 & 0.0405 & 0.0554 & 0.0538 \\
\hline \multirow{2}{*}{$A G E \times C O N T R O L$} & 0.0080 & 0.0087 & 0.0135 & 0.0131 \\
\hline & 0.0017 & 0.0027 & 0.0034 & 0.0034 \\
\hline \multicolumn{5}{|l|}{ Conditioning variables } \\
\hline \multirow{2}{*}{ RATIO $_{-1}$} & 0.3105 & 0.3190 & 0.2980 & 0.3830 \\
\hline & 0.0604 & 0.0566 & 0.0665 & 0.0623 \\
\hline \multirow{2}{*}{$A G E$} & 0.0066 & 0.0070 & 0.0108 & 0.0081 \\
\hline & 0.0036 & 0.0016 & 0.0022 & 0.0018 \\
\hline \multicolumn{5}{|l|}{ Summary and diagnostic statistics } \\
\hline Number of observations & 290 & 290 & 290 & 290 \\
\hline Standard error & 0.0098 & 0.0098 & 0.0094 & 0.0100 \\
\hline Sargan Test (p value) & 0.3000 & 0.3083 & 0.3111 & 0.1241 \\
\hline 1st-order serial correlation ( $p$ value) & 0.0041 & 0.0032 & 0.0031 & 0.0013 \\
\hline 2nd-order serial correlation ( $p$ value) & 0.9100 & 0.6945 & 0.9052 & 0.6896 \\
\hline
\end{tabular}


Table A2: More Models of Real Asset Growth (GROWTH)

The table reports GMM coefficients using lags up to order 3 as instruments for the lagged dependent variable and up to order 2 as instruments for the default variables. Year fixed effects are also used. Standard errors are in italics, and coefficients significant at the 5\% level are in bold.

\begin{tabular}{|c|c|c|c|c|}
\hline & \multicolumn{4}{|c|}{ type of institution } \\
\hline & VOICE & $L A W$ & EFFECT & QUALITY \\
\hline \multicolumn{5}{|l|}{ Adverse selection } \\
\hline \multirow{2}{*}{ DEFAULT } & -1.7600 & -1.7496 & -1.7845 & -2.0338 \\
\hline & 0.5444 & 0.5505 & 0.5037 & 0.5440 \\
\hline \multirow{2}{*}{$A G E \times D E F A U L T$} & 0.0430 & 0.0408 & 0.0480 & 0.0538 \\
\hline & 0.0168 & 0.0173 & 0.0152 & 0.0173 \\
\hline \multicolumn{5}{|l|}{ Moral hazard } \\
\hline \multirow{2}{*}{ institution } & -0.1678 & 0.2664 & -0.0180 & 0.1442 \\
\hline & 0.1397 & 0.1208 & 0.0984 & 0.1003 \\
\hline \multirow{2}{*}{ CONTROL } & -0.1398 & -0.1659 & -0.1628 & -0.1197 \\
\hline & 0.1102 & 0.0901 & 0.0983 & 0.0915 \\
\hline \multicolumn{5}{|l|}{ Conditioning variables } \\
\hline \multirow{2}{*}{ GROWTH $_{-1}$} & 0.0345 & 0.0607 & 0.0744 & 0.0291 \\
\hline & 0.0709 & 0.0751 & 0.0776 & 0.0736 \\
\hline \multirow{2}{*}{$A G E$} & -0.0063 & -0.0056 & -0.0068 & -0.0072 \\
\hline & 0.0016 & 0.0017 & 0.0015 & 0.0016 \\
\hline \multirow{2}{*}{ GDPGR } & 1.1254 & 0.8440 & 0.8221 & 1.0462 \\
\hline & 0.4479 & 0.4271 & 0.4524 & 0.4633 \\
\hline \multicolumn{5}{|l|}{ Summary and diagnostic statistics } \\
\hline Number of observations & 213 & 213 & 213 & 213 \\
\hline Standard error & 0.0560 & 0.0572 & 0.0581 & 0.0559 \\
\hline Sargan Test (p value) & 0.2485 & 0.5040 & 0.1118 & 0.1329 \\
\hline 1st-order serial correlation ( $p$ value) & 0.0063 & 0.0042 & 0.0040 & 0.0059 \\
\hline 2nd-order serial correlation ( $p$ value) & 0.4200 & 0.5738 & 0.3573 & 0.6899 \\
\hline
\end{tabular}


Figure 1: distribution of RATIO

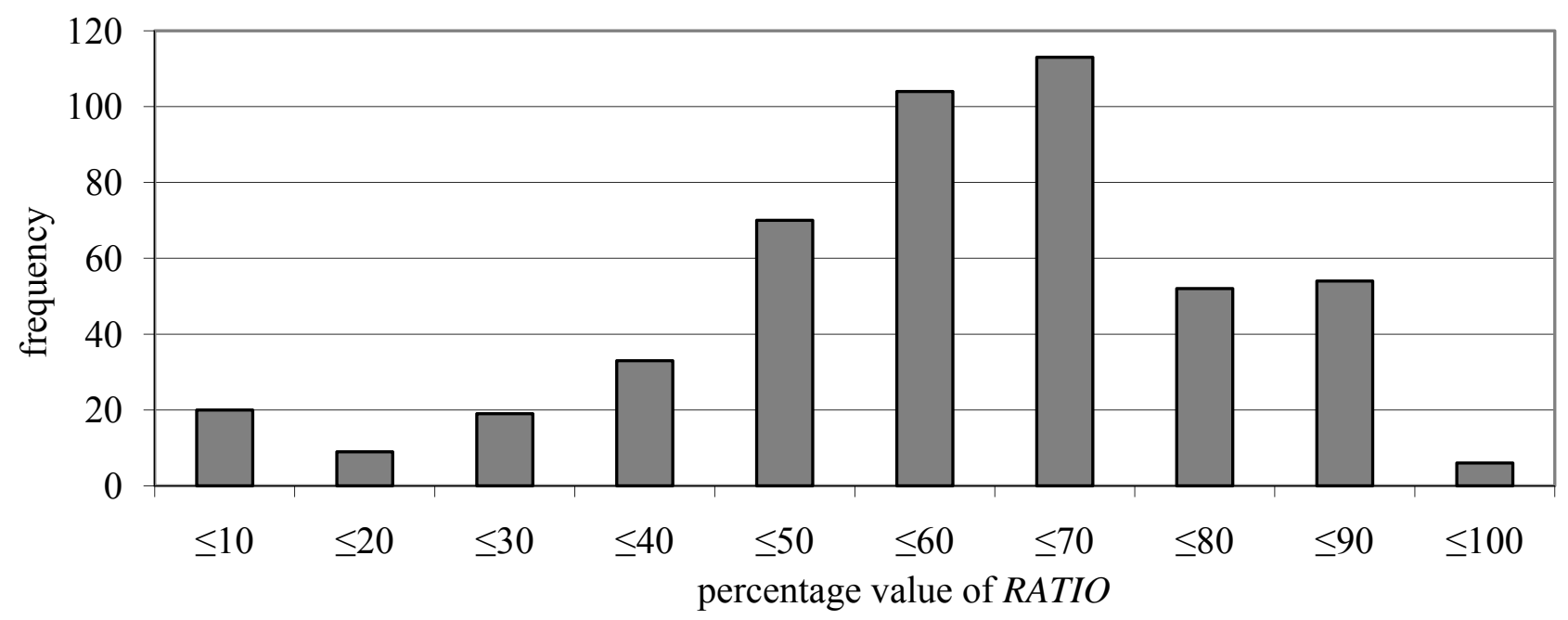

Figure 2: distribution of GROWTH

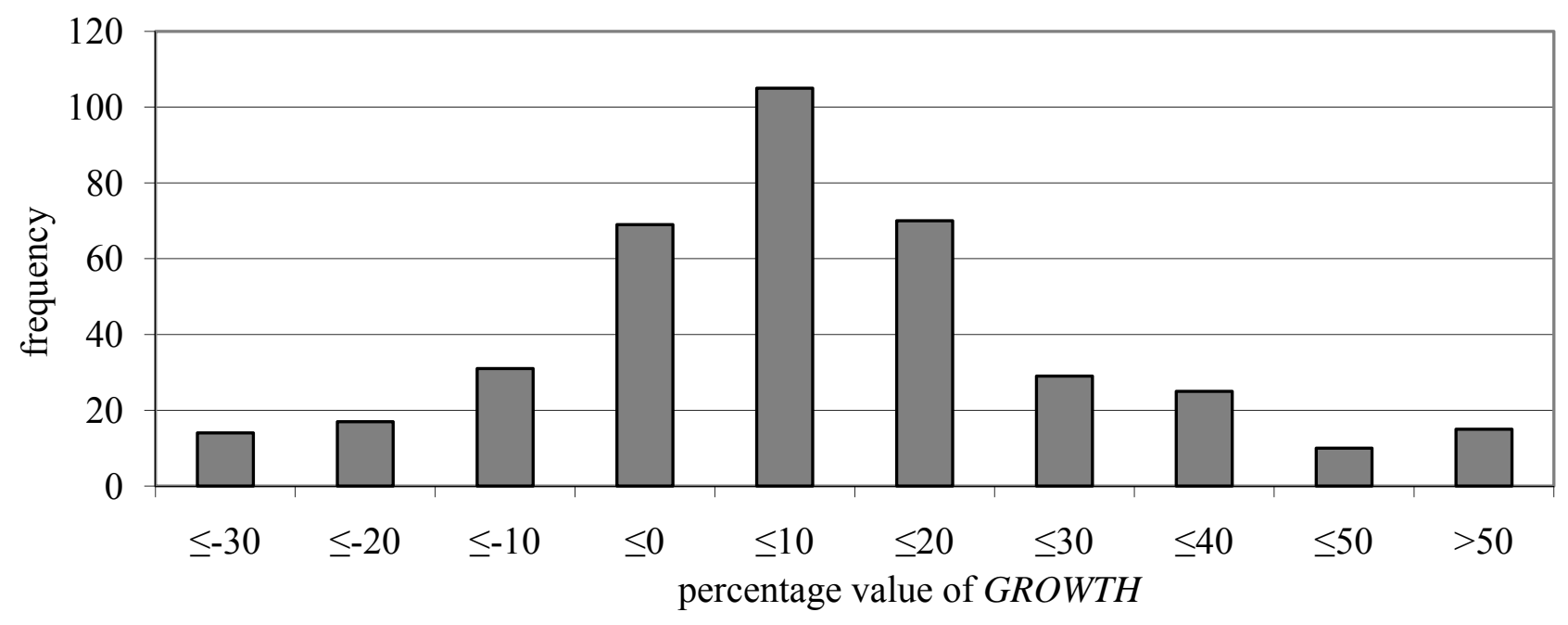

Figure 3: distribution of $A G E$

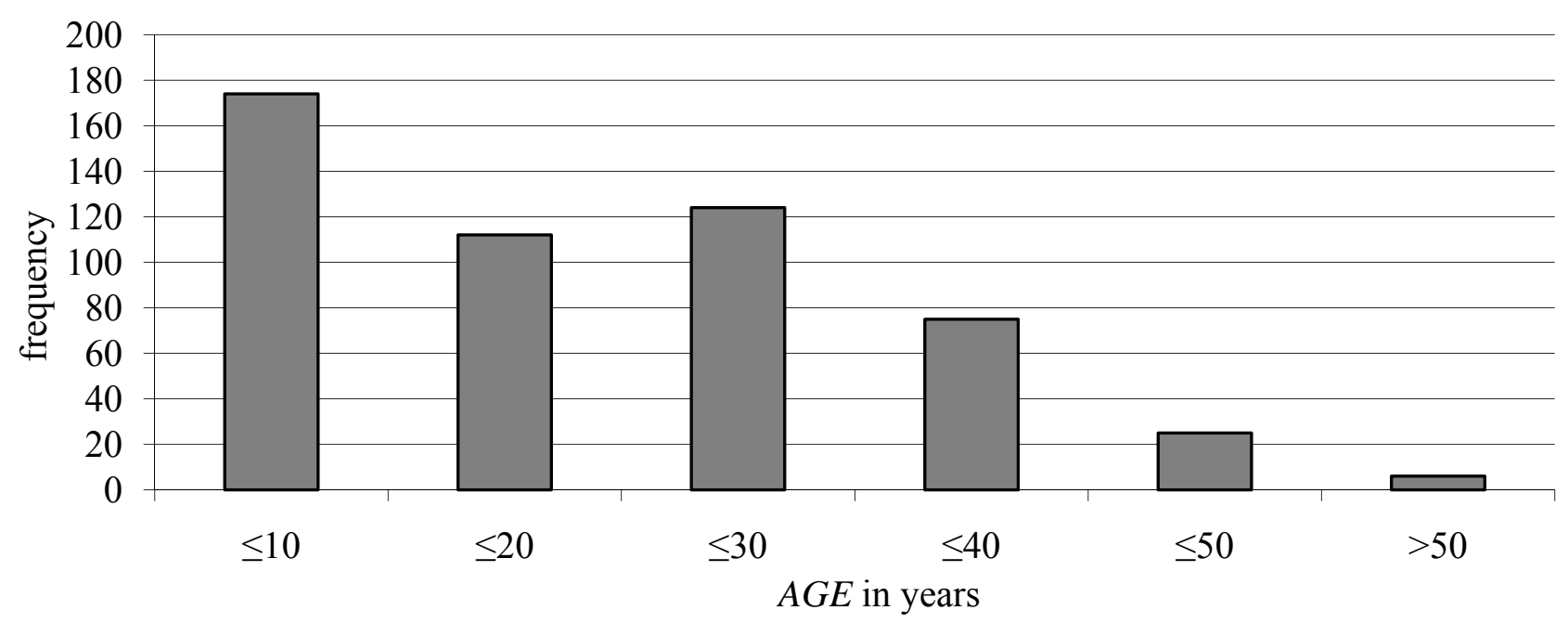


Figure 4: distribution of FOREIGN

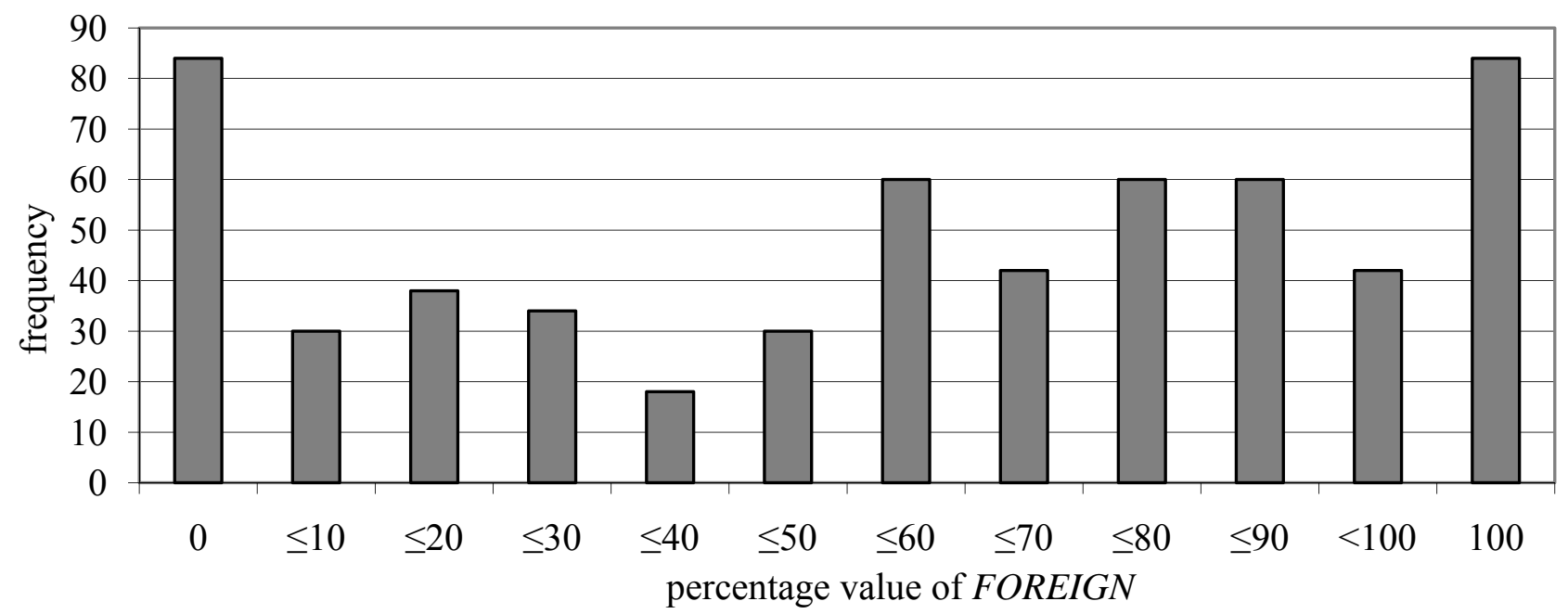

Figure 4: distribution of GOVERNMENT

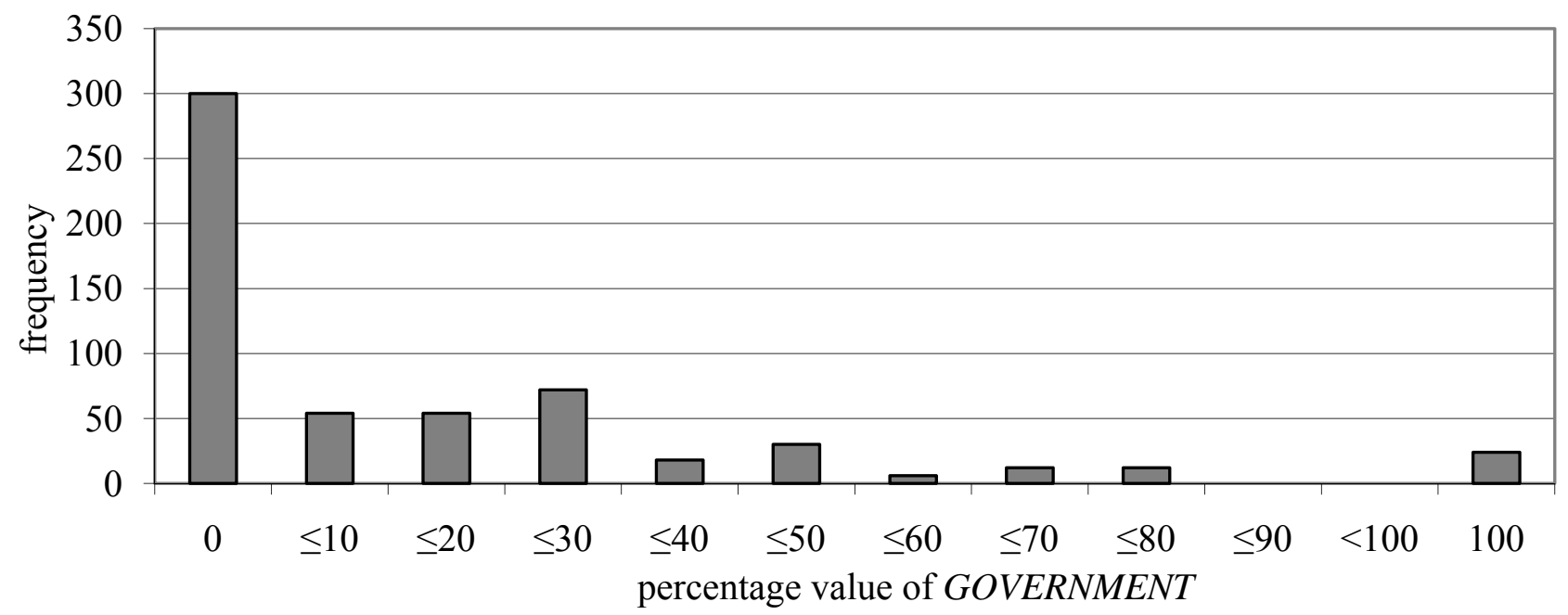

Figure 6: distribution of private domestic share in bank ownership

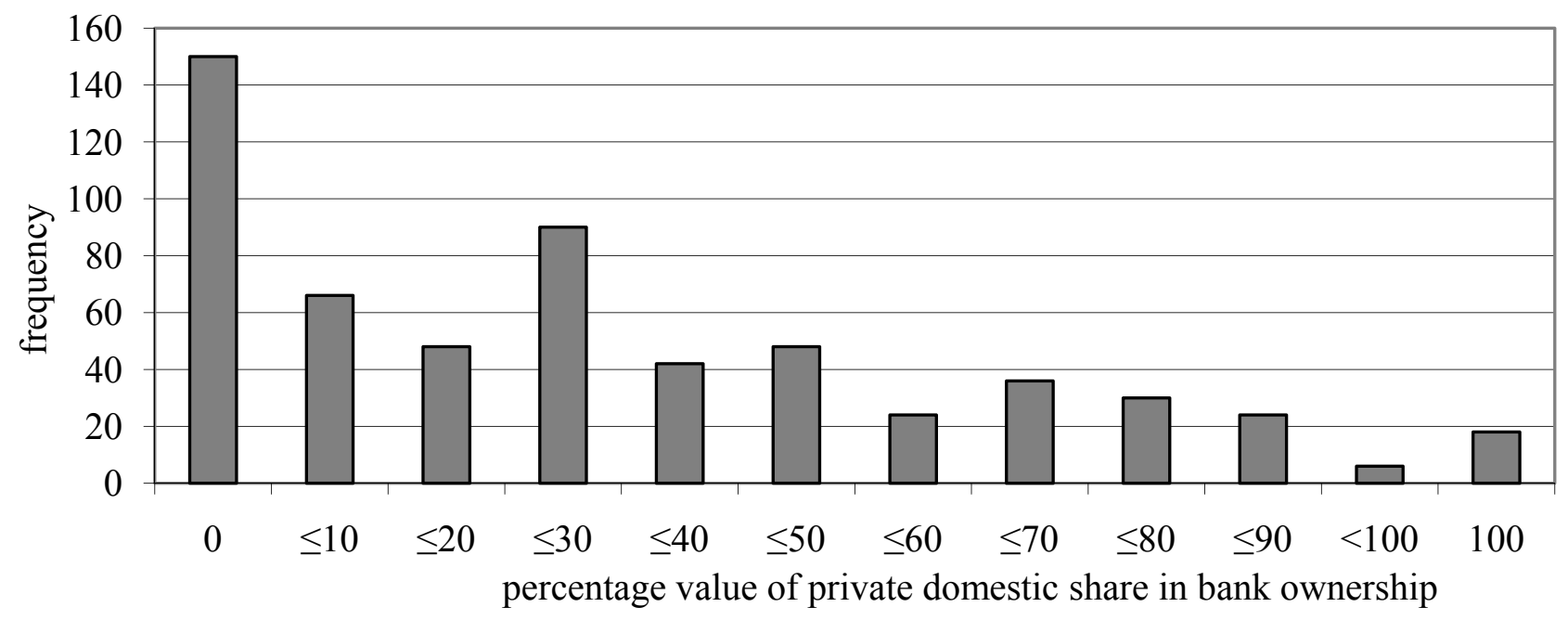

